\title{
Shifting negative migrant categories to encourage embrace and inclusivity: Perspective from Matthew 22:34-40
}

\begin{abstract}
Author:
Christopher Magezi ${ }^{1}$ (]

Affiliation:

${ }^{1}$ Unit for Reformational

Theology and the Development of the South African Society, Faculty of Theology, North-West University, Vanderbijlpark, South Africa
\end{abstract}

Corresponding author: Christopher Magezi, magezichristopher@gmail. com

\section{Dates:}

Received: 31 July 2020

Accepted: 18 Jan. 2021

Published: 30 Mar. 2021

How to cite this article: Magezi, C., 2021, 'Shifting negative migrant categories to encourage embrace and inclusivity: Perspective from Matthew 22:34-40', In die Skriflig 55(1), a2664. https://doi. org/10.4102/ids.v55i1.2664

\section{Copyright:}

(C) 2021. The Authors.

Licensee: AOSIS. This work is licensed under the Creative Commons Attribution License.

Read online:

Scan this QR
code with your
smart phone or
mobile device
to read online.

\begin{abstract}
Despite extensive theological research that has been conducted in response to the various challenges that are faced by international migrants, labelling is still prevalent. Derogatory stereotypes, names, categories and other labels continue to be used at the expense of foreigners, thus precipitating xenophobia. With the above-mentioned plight of international migrants in mind, the objective of this article is to respond to the ongoing challenge in which they are derisively labelled. The use of such derogatory stereotypes arguably exposes the migrants to many forms of discrimination, which mostly culminate in xenophobic violence. This article pays special attention to Matthew 22:34-40 as a critical text in developing a theological thinking that can shift negative categories in order to encourage the embrace and inclusion of migrants. Methodologically, this article is literature-based. The article begins by identifying the problem statement and then interacts with the aforementioned biblical text and pertinent literature in order to draw some theological implications to the identified challenge. Matthew 22:34-40 reveals how the God-man, Jesus Christ, confronts the limited definition which the Jews ascribe to the term neighbour. According to the skewed belief of the Jews, their neighbours were exclusively compatriot Jews. However, Jesus' conception of the term neighbour is inclusive of all fellow human beings because they are all created in the image of God and are the objects of God's love. Given the aforesaid, the article concludes by contending that before people designate derogatory stereotypes and labels that precipitate xenophobia, it is imperative to recognise each other, not only as neighbours but also as the bearers of God's image and objects of divine love.
\end{abstract}

Contribution: In this way, the contribution of this article is embedded in utilising Matthew 22:34-40 as an attempt to develop a theological thinking that shifts negative migrant categories to encourage embrace and inclusion.

Keywords: international migrants; migrants; church; political labels; stereotypes; Matthew 22:34-40; image of God; shifting negative migrant categories; embrace and inclusivity; theological thinking.

\section{Introduction}

The use of derogatory stereotypes and political labels on international migrants, ${ }^{1}$ including those who are legal, illegal, undocumented or irregular, as well as refugees and many other categories, contributes towards discrimination by the local communities and governments (Coetzee 2019; Fox, Moroşanu \& Szilassy 2012:680-695; Groody 2009:642; Lee \& Nerghes 2018:1; Magezi \& Magezi 2018:3; Stein 2018:n.p). Consequently, native communities, institutions, organisations and the governments of migrant-hosting nations avoid effectively addressing migrants' challenges and needs. Notably, the church has a role to play in shifting these negative migrant categories and encourage their embrace and inclusivity. That is, the church should develop theological thinking that challenges people to primarily perceive each other as of equal status before they stereotype or designate labels that result in negative perceptions of migrants.

1.This research recognised that there are internal and international dimensions of migration. The movement of people from their places of 'origin to a destination or from a place of birth to another destination across international borders' is termed international migration of 'origin 2013 2 The mation (international Organization for Migration [IOM] 2015.35). I speak of international migrants, I am refering to all people that move from their countries of origin to other countries for various reasons. Refugees are considered as a sub-category of international migrants that involuntarily migrate from one country to the other because of life-threatening disasters and predicaments such as natural disasters, climate change and political instabilities (IOM 2015:35; Skeldon 2013:2). Gilmore (2016), the Deputy High Commissioner for Human Rights, subscribed to the aforesaid understanding when utilising the word migrant as an overarching notion which refers to all people who have in common a lack of citizenship in their hosting countries. 
As such, by utilising Matthew 22:34-40, this article attempted to shift negative migrant categories to encourage embrace and inclusivity. However, before discussing Matthew 22:34-40, the ensuing section reviewed various scholars so as to sketch the study background and identify the problem of the research. The article concluded by bringing to the fore the implications of Matthew 22:34-40 in shifting migrant categories to encourage embrace and inclusivity.

\section{Study background: A terrain sketch and problem identification}

It is my firm conviction that the use of derogatory stereotypes and political labels on various categories of international migrants contributes towards anti-migrant discrimination by the native communities and governments of migrant-hosting nations (Coetzee 2019; Groody 2009:642; Magezi \& Magezi 2018:3). Such stereotypical labels, including accusations of criminality and stealing job opportunities from natives (Coetzee 2019; Groody 2009:642; Magezi \& Magezi 2018:3). In agreement with the aforementioned scholars, Tesfai (n.d.) acknowledged the dangers that are embedded in the way migrants are being labelled or categorised by helpfully observing that labelling:

\begin{abstract}
... influences our perception[s] of migrants as 'deserving' and 'undeserving' through an intrinsic ranking system. Take for instance a young British man moving to Thailand for work opportunities. He will be generally referred to as an expat rather than economic migrant; the former label being less stigmatised. Labelling migrants is political in nature. By labelling certain people as bogus asylum seekers or refugees, a distinction can be established between 'them' and 'us'. This hierarchy of labels dictates the level of hospitality granted to each category of migrant, but also fuels fear of unknown strangers and subsequent abuse. While these labels are necessary for legal purposes, it is important that they are not the only way that we understand the stories of the people who hold them. (n.p.)
\end{abstract}

Likewise, Zetter (1991:40) bemoaned the use of the abovementioned political labels and stereotypes on migrants and stated that 'far from clarifying an identity, the label conveys, instead, an extremely complex set of values, and judgments which are more than just definitional'. Here, the underlying issue is that perceiving migrants in political terms makes them susceptible to xenophobia and different forms of exploitation by the local communities and employers (Fox et al. 2012:680-695; Groody 2009:642; Lee \& Nerghes 2018:1; Magezi 2017:6; Stein 2018:n.p.).

Notably, in the South African context, discrimination is intensified by the fact that some South African nationals label African foreign nationals as 'Makwerekwere' (Manik \& Singh 2013:3). Manik and Singh (2013:3) and Azindow (2007:175) stated that the label carries undesirable connotations as it denotes African foreign nationals as deficient in speaking South African native languages. The pejorative word is also used to label African immigrants as dark skinned people from economically and culturally backward countries (Azindow 2007:175; Manik \& Singh 2013:3). Matsinhe
(2011:296) alluded to a study that revealed that West African nationals in Johannesburg complained that they were being called Makwerekwere by the natives. The term portrays the hatred of black foreign nationals in South Africa, whilst on the other hand, white foreign nationals are viewed as tourists (Matsinhe 2011:296).

Matsinhe (2011) further noted that the labelling of migrants as Makwerekwere resulted in a joint declaration by the Southern African Migration Project (SAMP) and the South African Human Rights Commission (SAHRC) that:

\begin{abstract}
... the victimisation of black South Africans is being replaced by the victimisation of African foreigners, noting that not only are more and more citizens becoming more xenophobic but they also perceive almost exclusively. (p. 296)
\end{abstract}

Furthermore, migrants are also stereotyped in many and different ways by their host communities (Brunsdon \& Magezi 2020). For instance, in South Africa, this stereotyping mainly revolves around perceived economic and criminal challenges (Brunsdon \& Magezi 2020). At this juncture, it is important to note that the connection between migrants and criminal activities is not coincidental (Brunsdon \& Magezi 2020), as it is deeply rooted in incidents where migrants have been associated with specific unlawful acts, as noted in research studies by Plucinka (2015:n.p.), Louw (2016:1-3) and Magezi (2018:211-213). The aforementioned scholars highlight the involvement of some international migrants in criminal activities. In their different ways, these authors note the Paris Massacre ${ }^{2}$ of 13 November 2015 as an example of incidents that triggered European nations to be wary of migrants. Although Plucinka (2015) contested the correctness of such accusations, it is beyond question that the Paris killings activated diverse approaches and responses by numerous European countries. That is, because of the Paris Massacre, France, Italy and Belgium buffered their border security to rebuff Syrian refugees (Plucinka 2015).

Slovakia and the Czech Republic, which also associated the Paris Massacre to the Syrian refugees, were no longer willing to accept refugees, arguing that it was going to be difficult to integrate Muslim migrants in their native societies (Plucinka 2015). The aforesaid countries also feared that accepting Muslim migrants would open doors for terrorists to enter their nations (Plucinka 2015).

However, although no migrant in South Africa has ever been arraigned for terrorist activities, it is not uncommon for foreign nationals to be associated with criminal activities (Coetzee 2019), and this has caused a deep dislike of foreigners Coetzee 2019; IOM 2009:18; Van Lennep 2019). Coetzee (2019:n.p; cf. International Organization for Migration [IOM] 2009:20; Manik \& Singh 2013:1) reported that:

2 .In the sub-Saharan African context, the Human Rights Watch (2015) reported Kenya as one of the countries that experienced the killing of many Somalian refuges. The as one of the countries that experienced the kiling of many Somalian refugees. The Government of Kenya responded by tightening secunity at its border posts, however, it was criticised by the international community for doing that. This clearly indicates that one of the foremost challenges faced by many migrant hosting nations is that in trying to openly welcome migrants, they end up being in danger. 
It would appear that the majority of South Africans hold very negative views about the impact of international migrants on South African society in which a significant share of the public believes that immigrants are a major driver of unemployment and crime.

The evidence used to link foreign nationals to criminal activities in South Africa is largely drawn from the number of international migrants in South African prisons (Maravanyika 2016:1). Whilst I acknowledge that foreign nationals, just like the native South Africans, are involved in criminal activities, what is vexatious here is the exaggerated reporting pertaining to the number of foreign nationals in South African prisons by some South African government officials, which engenders xenophobia. Shezi (2017:1) noted that in a media briefing in 2017, David Mahlobo, the Minister of State Security, gave disputable figures on the population of foreign prisoners across South Africa. Heleta (2018) and Brunsdon and Magezi (2020) agree with Shezi (2017) and beg for more realistic reporting on the statistics of foreign nationals who are serving their time in South African prisons, as there is sometimes over-reporting of at least 2 million above the official figures, which tends to create a sense of panic amongst the local population, leading them to blame migrants for local deficits, such as the high crime rate and unemployment (Shezi 2017).

It is important to note that not all migrants are illegal or get involved in criminal activities, and thus, they should not be labelled as criminals without substantial evidence (Plucinka 2015). As well, it is one thing to be a refugee and another to be a criminal, so these two categories must not be conflated (Plucinka 2015). It is apparent that both migrants and natives get involved in crime, so there is no need to point fingers at the latter as if they are the only ones who commit crime (Shezi 2017:1). Ascribing these negative labels to migrants only exacerbates xenophobia and the migration dilemma, instead of yielding sustainable solutions to this global crisis, that is, developing proper programmes of integrating migrants into the local population (Brunsdon \& Magezi 2020).

Furthermore, these stereotypes result in national governments and local communities of host countries failing to perceive the need to address the material needs of migrants.

In my view, whilst the media and governments should be on the frontline of deconstructing these stereotypes and labels that are ascribed to migrants (Heleta 2018), I concur with Brunsdon and Magezi (2020) that the church should also play its role as a community of God that is divinely sanctioned to look after vulnerable people. Stated otherwise, because these perceptions and stereotypes of migrants have become firmly rooted in society, the church is reminded of its own calling to be a spiritual community that ought to respond in alternative ways to the needs of the vulnerable, such as migrants. This call is rendered in both the Old and New Testaments (cf. Ex 22:21-27 and 23:9; Lv 19:33-37; Dt 24:14-22 and 10:12-22; Mt 25:31 ff.). Given this, the following question is at stake: What kind of theological thinking can be developed to ensure that native people can view foreign nationals as people who are equal to them in status, and deserve full human dignity and respect, regardless of their different national, religious, cultural and linguistic backgrounds? In other terms, the question may be stated as: What kind of theological thinking can be developed to ensure that natives can view migrants as people of equal status who deserve to be embraced and included rather than perceived as criminals, illegal or undocumented migrants?

To answer the above question, I propose Matthew 22:34-40 as a critical text in shifting negative migrant stereotypes and categories and encourage embrace and inclusivity. As alluded to above, Matthew 22:34-40 poignantly reveals the inseparability of Christians' love for God from their service to fellow humanity. To accomplish the proposed task, the forthcoming section discusses Matthew 22:34-40 by paying close attention to the background, general and immediate contexts of the passage and the hermeneutical (interpretation) issues associated with the text. The fourth section will proceed to discern some emerging theological thinking from the proposed text that can shift negative migrant categories to encourage host governments and communities to embrace and include migrants, regardless of their aforementioned backgrounds.

\section{Discussing Matthew 22:34-40 as a critical text in shifting negative migrant categories to encourage embrace and inclusivity}

\section{Locating Matthew 22:34-40 within the larger context of the theme and purpose of Matthew's gospel}

Together with Bauckham (1999:872-882) and Schnabel (2005:3), I argue that the gospel of Matthew was not written to a single church, but to all the churches in the regions that Matthew was active as a preacher and teacher. ${ }^{3}$ There are two reasons to affirm the aforementioned. Firstly, as Schnabel (2005:3, cf. Bauckham 1999:872-882) noted, the initial reason is that it is most unlikely for the author to have written a book of this huge size to an audience '.. of thirty, forty, or fifty people - the size of the average house church'. Secondly, Bauckham (1999:876, cf. Schnabel 2005:3) notes that the New Testament constitutes overwhelming evidence that the churches of the first century were in consistent contact with each other. To use Bauckham's (1999) words:

The context in which the early Christian movement developed was not conducive to parochialism; quite the opposite. Frequent contact between the churches scattered across the empire was natural in such a society, but in addition to Christian participation in the ordinary mobility of this society, much communication was deliberately fostered between the churches. (p. 876)

3. However, I was conscious that this notion was refuted by other scholars. For more information on the dismissal of this view, one may consult Ulrich 2007. I, however, information on the dismissal of this view, one may consult Ulrich 2007. I, however,
did not venture into this debate because it was not the main argument of this article. 
A considerable number of scholars (i.e. Botha 2006; Heffern 1912; Heil 1991:538-545; Hill 1972; Hutchison 2001; Lee 2007; Morris 1992; Nowell 2008) have proposed that Matthew's gospel is interested in issues such as the relationship between Jewish and Gentile Christians and the role of Gentiles in Matthew's community.

However, I argue together with Schnabel (2005:1) that the "theme of "mission" has long been recognized as one of the fundamental interests of the author of the First Gospel'. Schnabel (2005:1) surveyed and explained the following three areas, which demonstrate mission as a key concept in Matthew's gospel, namely: (1) Matthew's narrative, (2) the historical context of Matthew and (3) Matthew's gospel and theology. For instance, in focusing on the narrative of Matthew, Schnabel (2005:4) is in line with a considerable number of scholars such as Kiddler (2015:115), Viljoen (2011:2), Kruger (2007:1), Combrink (1983:77) and Schweizer (1975:21-26) that contend that Matthew commenced his gospel by linking Jesus with David and Abraham (Mt 1:1) so as to demonstrate that the Old Testament hope of new creation was fulfilled in Jesus Christ, the messianic king of Israel and the heir of the Davidic promises. To further elaborate, in designating Jesus Christ as the son of Abraham (Mt 1:1), Matthew was aiming at establishing Jesus Christ as the one who would fulfil God's promises to the patriarchs of Israel that all the nations (Jews and Gentiles) of the earth would be blessed through Abraham and his descendants, as stated in Genesis 12:3, 18:18, 22:18 (Combrink 1983:77; Kiddler 2015:115; Schnabel 2005:4).

Furthermore, from a systematic conception of the Old and New Testaments, Horton (2011:19-107), Torrance (2008:44), Wright (1991:36), Magezi and Magezi (2017:155-158) and Kruger (2007:2) all agree with the foregoing assertion and advance Christ as the one who fulfils the Old Testament covenant promises that God designed to achieve through Abraham and his descendants (the Israelites), as his covenant people. For instance, Torrance (2008:45) views Christ as the centre of redemptive history, because the Old Testament looks forward to the fulfilment of the redemptive promises in and through Christ, whilst the New Testament looks back to the promises of the redemptive history that culminate in Christ. This concept can be encapsulated by affirming Torrance's (2008) ensuing words:

\footnotetext{
... the center of gravity is in the incarnation itself, to which the OT is stretched out in expectation and the NT looks back in engulfment. This one movement throughout the OT and NT is the movement of God's grace in which he renews the bond between himself to man in such a way as to assume human nature and existence into oneness with himself. (p. 45)
}

In substantiation, together with Lee (2007:49 ff.) and Morris (1992:23), I argue that the inclusion of women (such as Tamar, Rahab, Ruth, etc.) from Gentile ethnic groups in Matthew's genealogy also served to illustrate that Matthew's purpose was to present Jesus Christ as the saviour of all people, including the Gentiles, thus fulfilling the Abrahamic promises of Genesis 12:3. In this way, one can contend that although
Matthew wrote as a historian who knew that Jesus focused his proclamation of the dawn of God's kingdom on Israel rather than on Gentiles (Schnabel 2005:1), it is apparent that Matthew's gospel commenced with Jesus as the one who was fulfilling the role of Israel in bringing salvation to people of all nations and subsequently concluded with the Great Commission in which Jesus sanctioned his disciples to preach the gospel to all nations (Bauer 2019:240-276; Mt 28:16-20). Thus, the book of Matthew revealed that after the God-man, Jesus Christ, had fulfilled the Old Testament-promised redemption for humankind through his incarnation, life, death and resurrection, he proceeded to commission his disciples to undertake the universal mission of preaching the gospel to all nations (Bauer 2019:240-276; Mt 28:16-20). Given this, although there are many other themes in the gospel of Matthew, I conclude together with Schnabel (2005) that:

The Gospel of Matthew is a narrative, in the first century C.E. mission was not just a concept but a historical reality, and both Matthew's Gospel and mission represent theological convictions. An analysis of relevant narrative, theological, and historical perspectives suggests that the author of the First Gospel wrote as a theologian who had an intense interest in the universal mission of the church, that he had perhaps personal experience of missionary activity leading people to faith in Jesus Christ and establishing churches, and that he also wrote as a historian who knew that Jesus focused his proclamation of the dawn of God's kingdom on Israel rather than on Gentiles. (p. 1)

In locating Matthew 22:34-40 within the larger context of the theme of Jesus' mission to the Jews and the Gentiles in Matthew's gospel, I opine that the aforesaid passage was situated within the conflict between the Jewish religious leaders and Jesus and his followers. The text forms a central theme throughout Matthew's Gospel (Stanton 1992:113-145; Viljoen 2015:2), as the next section shall establish. The passage also constitutes a significant message, which is inherent within the mission of the Church. This message should be taught and embodied by both Jewish and Gentile followers of Jesus Christ, as it is the Great Commandment, which is significant in developing an authentic theological response to migrants' challenges that can serve as ethical frameworks for Christians because it reveals a theological thinking that can shift negative migrant categories to encourage embrace and inclusivity, as discussed in the ensuing sections.

\section{The general and immediate context of Matthew 22:34-40}

In establishing the general context of the chapter, Matthew 22 is a continuation of the hostile interrogation of Jesus that commenced in Matthew 21, which came after Jesus' triumphant entry into Jerusalem (Mt 21:1-22), where he later on suffered rejection and death for the sins of the world. Immediately after Jesus' triumphant entry into Jerusalem to fulfil the words of the Old Testament prophets (Mt 21:4-5) (and redemption for humankind), his authority was questioned by the chief priests and the elders of the Jewish community. This interrogation came after Jesus had driven out the people who were doing business in the temple and subsequently performed some miracles (Mt 21:23-46). 
Amongst many other things, Matthew 22 constitutes Jesus' instructions, which were given in the form of a parable concerning the rejection of the Jews and the calling of the Gentiles (Mt 22:1-10) and the danger of hypocrisy in the profession of Christianity (Mt 22:11-14). Thereafter, in Matthew 22:15-22, the chief priests and elders interrogated Jesus about the legitimacy of paying tax to Caesar and, in Matthew 22:23-33, they asked him about marriage in the resurrection. In Matthew 22:34-40, the Jewish leaders asked Jesus to name the greatest commandment. Together with Viljoen (2015), I argue that:

The questions of these challenges are posed in such a manner that whatever Jesus answers, his answer would be embarrassing and damaging to his credibility. However, Jesus time and again overcomes these challenges with his unexpected answers. (p. 1)

Matthew 22:41-45 concluded with Jesus taking the lead as he questioned the Pharisees about his identity (Viljoen 2015:1). At this juncture, the Pharisees could not respond to Jesus' questions and, as indicated at the end of the chapter, they could no longer dare to question Jesus (Mt 22:45) (Meier 2009:482-486; Viljoen 2015:1).

However, in paying special attention to Matthew 22:34-40, which narrated the discourse in which a Jewish law expert interrogated Jesus with regard to the greatest commandment, the ensuing sub-section discussed how Jesus' response revealed the inseparability of people's love for God and fellow human beings. The aforementioned theology and its interrelated facets, which were the primary focus of the discussion of Matthew 22:34-40 below, were significant in developing a theological thinking that could shift negative migrant categories to encourage embrace and inclusivity.

\section{The indivisibility of Christians' love for God and their service to fellow human beings in Matthew 22:34-40}

In Matthew 22:34-40, Jesus brought to the fore the indivisibility of people's love for God and fellow human beings or neighbours, because God is the source of all love (Davies \& Allison 1997:244; Hagner 1995:648; Luz 2007:366; Micth \& Sri 2010:289; Morris 1992:563; Park 2009:62-70; Turner 2008:537). Again, in Matthew 22:34-40, the Pharisees came together in attempt to trick Jesus with complicated questions (cf. Blomberg 1992:334; Mitch \& Sri 2010:288; Morris 1992:562; Turner 2008:535). There was an expert of the law or lawyer (nomikos in Greek) amongst these Pharisees and he asked Jesus regarding the supreme law (nomads) or commandment (Mt 22:34-35) (Blomberg 1992:334). However, as the aim of the Pharisees was to trick Jesus, one can deduce that at that point in time, they also wanted to establish whether Jesus was who he claimed to be.

One can argue that the lawyer seemed to be concerned about the greatest commandment from the Ten Commandments that God gave to the Israelites through Moses (Mounce 1985:210; Park 2009:61-69).

However, Jesus' answer exceeded expectations, because he stated the first and second greatest commandments (Mt 22:37-39). Park (2009:61-69) and Mounce (1985:210) rightly observed that Jesus' answer came from Deuteronomy 6:4-5, thus corresponding with the Shema (the fundamental Jewish Creed) that opens by affirming the monotheistic God of the Israelites, whom the Israelites have to love with all their hearts, souls and might (Blomberg 1992:335). In Matthew 22:37, Jesus' response revealed that the most important commandment was to love God with one's heart, soul and mind (Blomberg 1992:335). This account was also recorded in Mark 12:30 and Luke 10:27. In trying to discern the differences amongst the versions of this story in different gospels and Deuteronomy 6:4-5, it can be noted that Matthew substituted strength with mind, whilst the accounts in Luke 10:27 and Mark 12:30 both used strength and mind (France 1985:322-323; Mounce 1985:210, cf. Furnish 1998:7-8; Park 2009:61-69). However, although there are differences in these gospel passages, I agree with Morris (1992:563) that the disparities are insignificant, because all the cited verses advance that humanity should love God wholeheartedly, that is, with all that they have and all that they are.

Blomberg (1992:335) and Viljoen (2015:6, cf. Davies \& Allison 2004:241; Gerhardsson 1976:140) agree with the aforementioned conception that, in Jewish tradition, the human faculties that are mentioned in Matthew 22:37 represent the entire person. This implies that one cannot love God with only one faculty, without involving others (Blomberg 1992:335; Viljoen 2015:6, cf. Davies \& Allison 2004:241; Gerhardsson 1976:140). Viljoen (2015) examines how these faculties are related in both the Old and New Testaments. In explaining the function of the first faculty that Jesus referred to namely loving God with 'all your hearts', Viljoen (2015:6, cf. Jacob 1974:626; Walker 2000:563) noted that this faculty is mentioned 800 times in the Bible; however, it is never used to refer 'to the literal physical pump that drives the blood'. Instead, both the Old and New Testaments (Jr 34:41; 1 Sm 12:20; Lk 16:15; Rm 5:5; 8:27; Eph 3:17; Mt 7:21; Jn 12:40; Ac 8:22) considered the heart as the 'centre of one's thoughts, will, knowledge, decisions and actions' (Viljoen 2015:6, cf. Baumgartel 1978:606-607; Behm 1978:611-613; Jacob 1974:626; Walker 2000:563). Furthermore, in line with Dihle (1974:609) and Schweizer (1974:637-656), Viljoen (2015:6) noted that the second faculty of loving God with 'all your soul' is etymologically related to $\psi v$ v $\chi \omega$ [blow] or breathe in a person, and its meaning is the same in both the Old and New Testaments (Ps 16:10, Mk 10:45, Ac 15:26). Consequently, I argue together with Viljoen (2015) that:

Reference to 'all your soul' therefore signifies that one should totally surrender one's life to God. Loving God with all your soul therefore implies that one should be devoted to God and his commandments even to the point of martyrdom. (p. 6)

The third faculty, namely loving God 'with all your mind', was not mentioned in Deuteronomy 6:5. However, in the 
New Testament, mind ( $\delta 1 \alpha v o i ́ \alpha)$ was considered 'as the seat of one's intellectual capacity, of reason, apprehension and insight' (cf. Mk 12:30; Heb 8:10; 10:16; Col 1:21; Eph 4:17-18) (Viljoen 2015:6). In view of the aforementioned discussion, Mounce (1985:210) helpfully understands Jesus in these different accounts and advances that 'God requires a love that involves the entire person'. Furthermore, Blomberg (1992:335), Barclay and Drane (2015:278) agreed with Mounce (1985) in their understanding that humankind's love for God, as in Matthew 22:27, cf. Luke 10:27, Mark 12:30, should be the kind that directs their emotions, thoughts and actions. Turner (2008, cf. Blomberg 1992:335; Nolland 2005:911) expanded this understanding when he (Turner 2008) underscored that:

The command to love God with one's heart, soul and mind means that one must love God with one's entire being ... not that one is responsible to love God with some of one's faculties and not with the others. (p. 536)

This way, the love of God is the supreme obligation in verse 38 (Mounce 1985:210; Nolland 2005:911-913; Wilkins 2002:138).

However, Jesus moved on to establish that although people's love for God was the fundamental and first commandment, it followed that it incorporated the other commandments (France 1985:323; Viljoen 2015:7).

That is, in expanding his answer to the lawyer's question, Jesus told him that the second greatest commandment was that 'You shall love your neighbour as yourself. On these two commandments rest all the law and the prophets' (Mt 22:39). Together with Williams (2018:120), Mounce (1985:210) and Furnish $(1998: 7,12)$, I argue that Jesus took this from Leviticus 19:18 and elevated it to be the second greatest commandment.

Here, one has to note that the lawyer had not asked about the second greatest commandment, but Jesus proceeded to bring the inseparable operation of these two commandments for a reason. Clark (1960:61) noted that Jesus went on to mention the second commandment in order to remind the law expert and the Jews who were present that, even if they were conscientious or legalistic in keeping the first greatest commandment, they still had been seriously guilty of omitting the second greatest commandment (France 1985:322). In agreement with Clark (1960) and France (1985), Viljoen $(2015: 10)$ noted that Jesus brought in the second greatest commandment at that juncture to address the limited Jewish definition of the term neighbour.

Commenting on Luke 10:25-37, which is related to Matthew 22:34-40, Blajer (2012:20) revisited the time of Jesus' earthly ministry to understand what the concept of neighbour meant to the Jews. Blajer's (2012:20) research revealed that during the material time, various groups of people such as the Pharisees, Sadducees and Essenes viewed the term neighbour as referring to all their Jewish compatriots and proselytes, whilst excluding 'non-Pharisees, the sons of darkness, heretics, or even personal enemies'. Thus, I concur with Viljoen (2015) that Jesus' teaching in Matthew 22:39 about loving one's neighbour differs from the traditional Jewish teachings which limited neighbourly love to fellow Israelites or Jews 5 . Stated otherwise:

Whilst the Jews predominantly limited neighbourly love to fellow Jews, proselytes or aliens within their borders, Jesus taught love beyond such borders. (Viljoen 2015:10)

In Jesus' view, the message of the law and the prophets depended on these two commandments, namely to love God with our whole beings and our neighbours as we love ourselves (Mt 22:40). The fact that the law and the prophets, and the message of the apostles are connected and inseparable in these two commandments means that 'all the other precepts and instructions in the Old Testament are ways in which these two fundamental principles find expression' (Mounce 1985:210-211). This means that it is impossible for Christians to observe any commandment of the Bible if one of these two were violated (France 1985:323; Mitch \& Sri 2010:289). In line with the preceding notion, Clark (1960:61) affirmed that Jesus was teaching the Jews of the actuality that the appropriate relationship of man with God also demanded the right relationship amongst fellow human beings. Similarly, France (1985) also underscored that Jesus' words in this context:

... direct us to understand and apply commandments of the law within the context of an obligation to love God and man, an obligation of which the commandments are themselves particular expression. (p. 323)

This can be taken to imply that Mitch and Sri (2010:289) are spot-on when they argue that Matthew 22:34-40 can be summarised to advance that the goal of Scripture is to bring humanity to love and serve God, as well as fellow human beings.

In other words, 'all the commandments are expressions of God's love. Love is the thrust of them all, and it is only as we love that we fulfill them' (Morris 1992:563). This, indeed, suggests a robust connection with God's laws in the Torah (cf. Ex 22:21-27, 23:9; Lv 19:33-37; Dt 24:14-22 and 10:12-22) regarding the manner the Israelites are commanded to love everyone, including the aliens amongst them. Having underscored this unity between the Old and New Testaments, Turner (2008:537) and Morris (1992:563) helpfully observed that by summarising all the precepts and instructions of the Old Testament in these proposed two commandments (Mt 22:37), Jesus was bringing out the interconnection between the vertical and horizontal aspects of love. The vertical aspect refers to our love for God and the horizontal aspect refers to our love for one another (neighbours) (Morris 1992:563).

In bringing the doctrine of creation to bear in the summary of the law and the prophets in Matthew 22:34-40, Mounce (1985:210) expanded Morris' (1992) above-mentioned understanding. Mounce (1985) brought the creation of human beings in the image of God as a thrust to our understanding of the relationship between the vertical and horizontal love mentioned in Matthew 22:34-40. It can also be rendered as '... from the love of God 5.France (1985:323, cf. France 1990:320) helpfully observes that a neighbour is not just a fellow Israelite, but Matthew 5:43-47 has already indicated that neighbours include your enemies. 
stems the ability and desire to love those who are created in the image of God' (Gn 1:26-27; Mounce 1985:210). In line with Morris (1992) and Mounce (1985), Patte (1987:314-315; cf. Mitch \& Sri 2010:288) argued that an examination of Jesus' response to the lawyer's question in this passage should help us to understand that our relationship with God results in love for one another. In Morris' (1992:563) view, during his earthly life, Jesus demonstrated the meaning of loving God and our neighbours by his deeds and actions. Jesus loved God wholeheartedly, with the demonstration of that love for others who were in desperate need, such as the sick and the needy, in many and different ways (Morris 1992:563). Accordingly, I argue together with Turner (2008, cf. Williams 2018:120) that by placing Leviticus 19:18 alongside Deuteronomy 6:5, Jesus was establishing that:

Loving God's creatures is of the same nature as, and accordingly just as important as, loving their creator ... Loving humans derives from loving their Creator, since Jesus' labeling of Deut 6:5 as the greatest and foremost commandment indicates that it must be viewed as foundational from Leviticus 19:18. (p. 537)

However, in light of the discussion undertaken in this section, it is important to note that I did not seek to provide a new interpretation for the proposed passage. In my view, if one assumes otherwise, he or she would be implying that I employed a superficial analysis of Matthew 22:34-40 or that Matthew 22:34-40 was harnessed to merely support my intention to change people's views on migrants. In responding to the aforesaid assumptions, I argue that I neither employed a superficial analysis of Matthew 22:34-40 nor harnessed Matthew 22:34-40 to solely support my intention to change people's perceptions on migrants. Rather, there is consensus on the author's interpretation of Matthew 22:34-40 in the scholarly guild, as the foregoing discussion attests. Having clarified the aforementioned, I argue that what is crucial at this juncture is to establish the link between Matthew 22:34-40 and its relevance in changing the negative views on migrants. In establishing the linkage, I argue that the principle of one's love for all human beings that emanates from Matthew 22:34-40 can be applied to how some natives generally perceive migrants. It is hoped that an objective articulation of the aforesaid principle, and subsequent obedience thereof, can prompt a change from the prevailing negative perceptions about migrants.

In my view, this arises from the conception that Jesus' teaching in Matthew 22:34-40 is for people to love all fellow human beings. This has huge implication on encouraging people to love migrants. Thus, Matthew 22:34-40 is a critical passage that can be utilised to challenge native people to consider an international migrant, who is the other, as a neighbour. This means that Matthew 22:34-40 can be employed to cultivate a constructive understanding of international migrants as neighbours who should be loved and cared for. This conception goes against the current discrimination of foreigners by some natives who use derogatory stereotypes and political labels that precipitate xenophobia. With the aforesaid in mind, the subsequent section drew some constructive theological implications from Matthew 22:34-40 that can possibly foster positive perceptions about migrants.

\section{The implications of Matthew 22:34-40 in shifting migrant categories to encourage embrace and inclusivity}

The discussion considered so far indicated that international migrants are labelled and categorised as illegal, undocumented, Makwerekwere and criminals, who allegedly increase the crime in host countries. In my view, these derogatory labels and categories precipitate xenophobia and degrade the identity of migrants, which is an undesirable situation (Groody 2009:642; Canoy et al. 2006; Magezi 2017:6; Zetter 1991:40). Currently, in his article titled The regressive power of labels of vulnerability affecting disabled asylum seekers in the UK, Yeo (2020) argued that the labels given to refugees undermine a rights-based approach. Lee and Nerghes (2018:1), in their article titled Refugee or Migrant Crisis? Labels, Perceived Agency and Sentiment Polarity in Online Discussions bemoaned that labels such as European migrant crisis and European refugee crisis that are used by the media, politicians and the online world '... [have] the potential to dictate the ways in which displaced people are received and perceived', as well as precipitate xenophobia and 'further disaffection and tension or elicit sympathy'. To use Lee and Nerghes (2018) own words:

The use of labels has the potential to shape the range of possibilities for understanding what the story is, and the way migrants and refugees are perceived. Negatively labelling and framing refugees and migrants may lead to serious problems in the host societies, where perceptions are significantly influenced. (p. 1)

This is because, far from clarifying the identity of migrants, the categories and labels given to migrants 'convey, instead, an extremely complex set of values, and judgments which are more than just definitional' (Zetter 1991:40, cf. Lee \& Nerghes 2018:1-13). In concurrence with the aforementioned scholars, Entman (1993) noted that by negatively frame labelling migrants in the ways that are discussed in this article, people are simply selecting:

... some aspects of a perceived reality and mak[ing] them more salient in a communicating text, in such a way as to promote a particular problem definition, causal interpretation, moral evaluation and/or treatment recommendation. (p. 52)

Given this, there is need to construct these categories by offering a theological thinking emerging from Matthew 22:34-40 that can possibly shift negative migrant categories to encourage migrant embrace and inclusivity, regardless of racial, religious, linguistic, national and cultural differences. This will even encourage native people, institutions and governments to address the challenges and needs of vulnerable migrants.

In Matthew 22:34-40, the law expert posed a question intended at disproving Jesus' identity. However, Jesus' response 
brought forth the inseparability of one's love for God and neighbours. The former is the greatest commandment and the latter is the second greatest. Notably, scholars such as Viljoen (2015:10), Park (2009:10) and Furnish (1998:7) consider these two inseparable commandments as foundational in Jesus' teaching on the Torah. For instance, Furnish (1998) notes that:

Matthew used the periscope of the double love command, love to God and neighbour, to summarize Jesus' teachings, as well as the laws of Moses, and to continue to demonstrate Jesus' prowess as a teacher in the presence of his Pharisaic opponents. (p. 7)

The aforesaid commandments are of utmost significance, as the message of the law and the prophets is all about loving God and our neighbours as we love ourselves (Mt 22:40).

The theological thinking that emerges from Matthew 22:34-40 is that, first and foremost, people should see others as God sees them (Morris 1992:563). Perceiving fellow human beings through the lens of God, who created them, is akin to calling people to view others as objects of God's love, who were created in the image of God (Morris 1992:563). Calling Matthew 22:34-40 a place of hope, Williams (2018) understands the aforementioned conception thus:

The greatest commandment is to love God and love our neighbour. Sounds simple, but we all know it is not. Jesus knew how difficult it is for us to love our neighbour, as we first need to see that person through the eyes of the One who created them. (p. 120)

Unfortunately, Matthew 22:34-40 confronts us with the actuality that the love for God is interconnected with the love for our fellow human beings, who are our neighbours. Anyone who claims to love God with all his being must love fellow humans (Morris 1992:563). In other words, as Clark (1960:61) notes, a proper relationship with God is premised on having an appropriate relationship with fellow human beings. In Matthew 22:34-40, Jesus brought forth the timeless truth that a neighbour was not only someone with whom one shared the same racial, religious, ethnic, national, linguistic and cultural backgrounds, as the Jews thought (Blajer 2012:20; Clark 1960:61; Viljoen 2015:10). Instead, Jesus taught love beyond such man-made borders and walls, by redefining neighbours as all fellow human beings, who bore the image of God and so should be treated and loved equally (Ryken 2009:541). In Ryken's (2009:541) view, just like the Jews of Jesus' time, the contemporary world still has a limited definition of neighbour and this hinders them from seeing all fellow-human beings as objects of God's love, who should be treated with equality and dignity. In Ryken's (2009) words:

The attitude is equally common today. Sometimes we draw the boundary along ethnic lines, excluding people from a different background. Sometimes we draw it along religious lines. We do a decent job of caring for other Christians, but we much less concern for people outside the church. Sometimes we draw the boundary along social lines, making a distinction between the deserving and the undeserving poor. Sometimes we simply exclude people whose problem seems too large for us to handle. (p. 541)
In recognition of the above theological thinking and the misconception of the definition of neighbour that emerges there, I argue that Matthew 22:34-40 reveals a compelling theological theory that challenges people to view fellow human beings in light of the doctrine of the imago dei [image of God], as indicated in Genesis 1:27. This perspective challenges people to view others as the bearers of the image of God, which should be treated with equality and dignity. That is, Matthew 22:34-40 reveals Jesus Christ as God the creator in action, who redefines the true meaning of neighbour to sinful mankind that most likely sees only those that share the same ethnic and national identities as equals (Barca 2011). In Matthew 22:34-40, Jesus challenged all people to see their fellow human beings as neighbours that deserve to be loved, thus challenging us to adopt proper theology that can result in the embracing and inclusion of all people, in this case migrants (Clark 1960:63).

That is, in approaching the second greatest commandment from a theological perspective, I concur with Clark (1960) that:

... only an adequate theology of God can produce an adequate concept of man. This seems to be the implication of the comments of Jesus, particularly the sequence in which he lists the two commandments. (p. 63)

However, as established before, this notion is in line with the conception that the goal of Scripture is to bring humanity to 'love and serve God', and their fellow human beings (Mitch \& Sri 2010:289). Clark (1960) understood the aforementioned notion well and linked the second greatest commandment with the writings of other New Testament authors as follows:

In writing to the church in Rome, Paul gave a strong emphasis to the second commandment. 'For this, Thou shalt not commit adultery. Thou shall not kill. Thou shalt not steal. Thou shalt not bear false witness. Thou shalt not covet; and if there be any other commandment, it is briefly comprehended in this saying, namely, Thou shalt love thy neighbour as thyself. Love worketh no ill to his neighbour: therefore love is the fulfilling of the law' (Rom 13:9-10). James went so far as to call this the royal law, 'If ye fulfil the royal law according to the scripture, Thou shalt love thy neighbour as thyself, ye do well' (James 2:8). (p. 63)

In line with Mitch and Sri (2010) and Clark (1960), Park (2009:61) observed that Matthew 22:34-40 does not only provide the gist of the Torah in two related commandments, instead, it is 'also a hermeneutical principle for interpreting the rest of the Torah'.

In light of the discussion considered so far in this article, one can robustly conclude by developing a theological theory that the labels and categories given to migrants by the native people and governments of migrant hosting nations, resulting in the discrimination and hatred of migrants, can be deconstructed by the theological aspects emerging from Matthew 22:34-40, particularly the doctrine that portrays all human beings as bearers of the image of God, who should be loved, viewed equally and treated with dignity (cf. Groody 2009:642; Hilkert 1995:190-204; Magezi \& Magezi 2018:1-12). 
In my view, the aforementioned doctrine, as it emerges from Matthew 22:34-40, can operate as a theological thinking that can shift negative migrant categories and encourage embrace and inclusivity. Stated otherwise, Matthew 22:34-40 reveals that all human beings are created in the image of God (the imago dei), as attested in Genesis 1:26-27, 5:1-3, 9:6 and 1 Corinthians 11:7. As such, the aforesaid doctrine, instead of the above-discussed derogatory labels and categories that precipitate xenophobia, should be the primary basis in perceiving migrants (Groody 2009:642; Hilkert 1995:190-204).

With the above-mentioned in mind, Christians, as representatives of God in the world, should advocate for the rights of migrants. That is, Christians should move from their comfort zones and do whatever it takes to make sure that native people and host governments perceive migrants, first and foremost, as people created in the image of God and, therefore, treat them as such. I concur with Williams (2018:122) that at a practical level, when Mathew 22:34-40 directly links our love for God with loving our neighbours, it means that people need to visit their neighbours and get to know them better in order to understand their experiences and contexts. Having said this, one can conclude together with Barca (2011) that the two related passages, namely Luke 10:25-37 and Matthew 22:34-40, confront us with relational anthropology that:

... demands not only recognition of the Other as neighbour, but as image of God. The double commandment of love demands an 'I-Thou' relationship with God and the Other who may be poor or non-poor, believer or not believer, but s/he is a person, child and image of God. (p. 62)

However, the question that arises is: what does it mean to shift negative migrant categories and encourage embrace and inclusivity of migrants in a practical way? In responding to this question, I argue that inclusivity and inclusion of migrants entail that the legal, spiritual, physical (material), psychological, environmental, practical and logistical support for both Christian and non-Christian migrants should be addressed (Magezi 2018:327), ${ }^{6}$ because when people move to other countries, they are virtually in a place of suspense or in-between in which they encounter many challenges that require the immediate help of the church, government institutions and non-governmental organisations (World Economic Forum 2017:14). In my view, practical help, embrace and inclusivity for migrants can only emanate when the discussed theology of Matthew 22:34-40 is used to shift their negative migrant categories.

\section{Conclusion}

This article has been a quest to develop theological thinking from Matthew 22:34-40 in order to shift negative migrant categories and encourage embrace and inclusivity. This quest arose from the fact that there are many derogatory stereotypes, categories and labels that are used at the expense of migrants, thus influencing negative perceptions of migrants. In my view, ascribing these negative views to migrants causes xenophobia and worsens the migration dilemma, instead of yielding sustainable solutions to this global crisis, that is, developing proper programmes of integrating migrants into the local population. For instance, in South Africa, migrants are often accused of stealing jobs from the natives, committing crime and causing overpopulation in prisons. Such derogatory stereotypes tend to overwhelm the local population with a sense of panic.

Consequently, this results in native people blaming migrants for local deficits, such as high crime and unemployment rates, thus culminating in xenophobia.

However, in employing Matthew 22:34-40 to develop a theological thinking that can shift negative migrant categories and encourage embrace and inclusivity, I argue that the proposed passage discloses that the goal of Scripture is to reveal the inseparability of loving God with one's whole being and loving one's neighbour as oneself. Instead of the limited contemporary Jewish definition, in Matthew 22:34-40, Jesus defined neighbours as all fellow human beings, regardless of whether they were migrants, poor or rich, because they were all created in the image of God. As such, they are the objects of God's love. With the aforesaid in mind, I argued that in Matthew 22:34-40, Jesus showed us that an adequate theology of God can produce an adequate concept of man. As a result, Jesus challenged people to primarily view fellow human beings as God saw them, that is, as the bearers of God's image. In other words, the underlying theological thinking emerging from Matthew 22:34-40 is that before people designate derogatory stereotypes, labels and categories that precipitate xenophobia, they should recognise each other, not only as neighbours, but as the bearers of the image of God and objects of his (God's) love. In this way, the primary interpretation and perception of human beings as the bearers of the image of God can shift negative migrant categories and encourage embrace and inclusivity.

\section{Acknowledgements}

The author would like to thank North-West University for paying the publication fee for this article.

\section{Competing interests}

The author declares that they have no financial or personal relationships that may have inappropriately influenced them in writing this article.

\section{Author's contribution}

C.M. is the sole author of this article.

\section{Ethical considerations}

This article followed all ethical standards for research without direct contact with human or animal subjects. 


\section{Funding information}

This research received no specific grant from any funding agency in the public, commercial or not-for-profit sectors.

\section{Data availability}

Data sharing is not applicable to this article as no new data were created or analysed in this study.

\section{Disclaimer}

The views and opinions expressed in this article are those of the author and do not necessarily reflect the official policy or position of any affiliated agency of the author.

\section{References}

Azindow, Y.M., 2007, 'Insiders and outsiders: Citizenship and xenophobia', African Studies Review 50(1), 175. https://doi.org/10.1353/arw.2005.0090

Barca, M.A.C., 2011, Virtue of ethics in the parable of the good Samaritan shaping Christian character, Boston College University Libraries, Boston, MA.

Barclay, W. \& Drane, J.W., 2015, The Gospel of Matthew, vol. 2, Westminster, Philadelphia, PA.

Bauckham, R., 1999, 'For whom were Gospels written?', HTS Teologiese Studies/ Theological Studies 55(4), 865-882. https://doi.org/10.4102/hts.v55i4.1638

Bauer, R., 2019, 'The theme of mission in Matthew's Gospel from the perspective of the great commission', The Asbury Journal 74(2), 240-276.

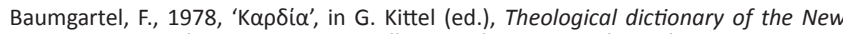
Testament, vol. 3, pp. 605-607, William Eerdmans, Grand Rapids, MI.

Behm, J., 1978, 'Heart', in G. Kittel (ed.), Theological dictionary of the New Testament, vol. 3, pp. 605-607, William Eerdmans, Grand Rapids, MI.

Blajer, P., 2012, The parable of the good Samaritan (Luke 10:25-37): Its function and purpose within the Lukan Journey Section, Catholic University of America, Washington, DC

Blomberg, C.L., 1992, Matthew, vol. 22, Broadman Press, Nashville, TN.

Botha, P.J., 2006, 'Tamar, Rahab, Ruth, and Mary - The bold women in Ephrem the Syrian's Hymn De Nativitae 9', Acta Patristica et Byzantina 17(1), 1-21. https:// doi.org/10.1080/10226486.2006.11745765

Brunsdon, A.R. \& Magezi, C., 2020, 'Fostering embracement, inclusion and integration of migrants in complex migration situations: A perspective from Matthew 25:31-46 and Hebrews 13:1-2', HTS Teologiese Studies/Theological Studies 76(2), a5966. https://doi.org/10.4102/hts.v76i2.5966

Canoy, M., Beutin, R., Horvath, A., Hubert, A., Lerais, F. \& Sochacki, M., 2006 Migration and public perception (Technical report), Bureau of European Policy Advisers (BEPA), European Commission, Luxembourg City.

Clark, C.A., 1960, 'Neglected commandment', Southwestern Journal of Theology 3(1), 61-73.

Coetzee, J., 2019, 'Prejudice against immigrants cuts across class and race', Mail \& Guardian, viewed 08 January 2020, from https://mg.co.za/article/2019-09-05 prejudice-against-immigrants-cuts-across-class-and-race.

Combrink, H.J.B., 1983, 'The structure of the Gospel of Matthew as Narrative', TynB $34,61-90$.

Davies, W.D. \& Allison D.C., 2004, A critical and exegetical commentary on the Gospel according to Saint Matthew, vol. 3, T \& T Clark International, London.

Davies, W.D. \& Allison, J., 1997, A critical and exegetical commentary on the Gospel according to Saint Matthew, vol. 3, Commentary on Mathew XIX-XXVII, International Critical commentary, T \& T Clark, Edinburgh.

Dihle, A., 1974, ' $\Psi$ uxn' in the Greek world', in G. Friedrich (ed.), Theological dictionary of the New Testament, vol. 9, pp. 608-617, William Eerdmans, Grand Rapids, MI.

Entman, R.M., 1993, 'Framing: Toward clarification of a fractured paradigm', Journal of Communication 43(4), 50-58. https://doi.org/10.1111/j.1460-2466.1993.tb01304.x

Fox, J., Moroşanu, L. \& Szilassy, E., 2012, 'The racialization of the new European migration to the UK', Sociology 45(4), 680-695. https://doi.org/10.1177/0038038511425558

France, R.T., 1985, Matthew: An introduction and commentary, Tyndale New Testament Commentaries, vol. 1, InterVarsity Press (IVP) Academic, Downers Grove, IL.

France, R.T., 1990, The Gospel according to Matthew: An introduction and commentary, InterVarsity Press, Leicester.

Furnish, F., 1998, 'The function of the double love command in Matthew 22:34-40', Andrews University Seminary Studies 36(1), 7-22.

Gerhardsson, B., 1976, 'The hermeneutic program in Matthew 22:37-40', in R. Hammerton-Kelly \& R. Scroggs (eds.), Jews, Greeks and Christians: Religious cultures in late antiquity, pp. 129-150, Brill, Leiden.
Gilmore, K., 2016, Keynote address: Side event migrants in transit by Deputy High Commissioner for human rights, viewed 20 May 2016, from http://www.ohchr.Org.

Groody, D.G., 2009, 'Crossing the divide: Foundations of a theology of migration and refugees', Theological Studies 70(3), 638-667. https://doi.org/10.1177/ 004056390907000306

Hagner, D.A., 1995, Matthew 14-28: Word biblical commentary 33b, Word Books, Dallas, TX.

Heffern, A.D., 1912, 'The four women in St. Matthew's genealogy of Christ', Journal of Biblical Literature 31(2), 69-81, viewed n.d., from http://biblicalstudies. gospelstudies.org.uk/pdf/jbl/1912_heffern.pdf.

Heil, J.P., 1991, 'The narrative role of the women in Matthew's genealogy', Biblica 72(4), 538-554.

Heleta, S., 2018, How many immigrants live in South Africa?, viewed 09 January 2020, from https://africasacountry.com/2018/10/how-many-immigrants-live-in-southafrica.

Hilkert, M.C., 1995, 'Cry beloved image: Rethinking the image of God', in A.O. Graff (ed.), The embrace of God: Feminist approaches to theological anthropology pp. 190-204, Orbis, Maryknoll, New York, NY.

Hill, D., 1972, 'The Gospel of Matthew', NCB, Marshall, Morgan and Scott, London.

Horton, M., 2011, Christian faith: A systematic theology for pilgrims in the way, Zondervan, Grand Rapids, MI.

Human Rights Watch, 2015, Kenya: Halt crackdown on Somalis, viewed 20 November 2019, from https://www.hrw.org/news/2014/04/11/kenya-halt-crackdownsomalis.

Hutchison, J.C., 2001, 'Women, gentiles and the Messianic mission in Matthew's genealogy', Bibliotheca Sacra 158(630), 152-164.

International Organization for Migration (IOM), 2009, Towards tolerance, law, and dignity: Addressing violence against foreign nationals in South Africa, viewed 02 July 2020, from https://southafrica.iom.int/publications/towards-tolerance-lawand-dignity-addressing-violence-against-foreign-nationals-south-africa.

International Organization for Migration (IOM), 2015, World migration report 2015, viewed 23 May 2020, from https://publications.iom.int/system/files/wmr2015_ en.pdf.

Jacob, E., 1974, 'The anthropology of the Old Testament', in G. Friedrich (ed.), Theological dictionary of the New Testament, vol. 9, pp. 617-631, William Eerdmans, Grand Rapids, MI.

Kiddler, S.J., 2015, 'Christ, the son of the living God: The theme of the chiastic structure of the Gospel of Matthew', Journal of the Adventist Theological Society 26(2), 149-170.

Kruger, B., 2007, On the road to becoming flesh: Israel as the womb of the incarnation in the theology of T. F. Torrance, viewed 20 June 2020, from http://www.fftorrance. org/journal/v3/participatio-2012-v3-2-Kruger-64-91.pdf.

Lee, J. \& Nerghes, A., 2018, 'Refugee or migrant crisis? Labels, perceived agency, and sentiment polarity in online discussions', Social Media + Society 1-22. https://doi. org/10.1177/2056305118785638

Lee, S., 2007, 'Matthew's concern for mission by including the four women (Matthew 1:1-17)', Torch Trinity Journal 10(1), 49-74.

Louw, D., 2016, 'The refugee dilemma and migrant crisis: Charity begins at home or being home to the homeless? The paradoxical stance in pastoral caregiving and the infiltration and perichoresis of compassion', HTS Teologiese Studies/ Theological Studies 72(2), a3267. https://doi.org/10.4102/hts.v72i2.3267

Luz, U., 2007, Matthew 1-7: A commentary, Fortress, Minneapolis, MN.

Magezi, C., 2017, 'Migration crisis and the church: A response to lacunae and considerations for Christian ministry engagement', Verbum et Ecclesia 38(1) a1671. https://doi.org/10.4102/ve.v38i1.1671

Magezi, C., 2018, 'Theological understandings of migration and church ministry model: A quest for holistic ministry to migrants in South Africa', PhD thesis, NorthWest University, Potchefstroom.

Magezi, C., 2020, 'Complexities of migration challenges in South Africa and a theological perspective: The good Samaritan framework', in A. Brunsdon (ed.), The human dilemma of displacement: Towards a practical theology and ecclesiology of home, pp. 51-84, AOSIS, Cape Town. https://doi.org/10.4102/ aosis.2020.BK198.03

Magezi, V. \& Magezi, C., 2017, 'An Adamic incarnational Christological framework as a theological approach for African contextual ministry', Missionalia 44(2), 152-174. https://doi.org/10.7832/44-2-111

Magezi, V. \& Magezi, C., 2018, 'Migration crisis and Christian response: From Daniel De Groody's image of God theological prism in migration theology to a migration practical theology ministerial approach and operative ecclesiology', HTS Teologiese Studies/Theological Studies 74(1), 4876. https://doi.org/10.4102/hts. v74i1.4876

Manik, S. \& Singh, A., 2013, 'Editorial: Love thy neighbours - Exploring and exposing xenophobia in social spaces in South Africa', in S. Manik \& A. Singh (eds.), Alternation: Interdisciplinary Journal for the Study of the Arts and Humanities in Southern Africa, Social Edition No. 7, pp. 1-8, CSSALL Durban, Durban.

Maravanyika, E.O., 2016, 'Understanding overcrowding in South African prisons', SABC News, viewed 07 July 2020, from www.sabc.co.za/.../Understanding-overcrowdingin-South-African-prisons-20161205.

Matsinhe, D.M., 2011, 'Africa's fear of itself: The ideology of Makwerekwere in South Africa', Third World Quarterly 32(2), 295-313. https://doi.org/10.1080/01436597. 2011.560470 
Meier, J.P., 2009, A marginal Jew: Rethinking the historical Jesus: Love and law, vol. 4 Yale University Press, New Haven, CT.

Mitch, C. \& Sri, E., 2010, The Gospel of Matthew: Catholic commentary on sacred scripture, Baker Academic, Grand Rapids, MI.

Morris, L., 1992, The Gospel according to Matthew, William B. Eerdmans, Grand Rapids, MI.

Mounce, R.H., 1985, Matthew: New international commentary, Hendrickson, Peabody, MA.

Nolland, J., 2005, The Gospel of Matthew: A commentary on the Greek text, William B. Eerdmans, Grand Rapids, MI.

Nowell, I., 2008, 'Jesus' great grandmothers: Mathew's four and more', The Catholic Biblical Quarterly 70(1), 1-15.

Park, E.C., 2009, 'A soteriological reading of the great commandment periscope in Matthew 22:34-40', Biblical Research 54, 61-78.

Patte, B., 1987, The Gospel according to Matthew: A structural commentary on Matthew's faith, Fortress Press, Philadelphia, PA.

Plucinka, J., 2015, The Paris attacks have put Europe's refugee crisis under renewed scrutiny, viewed 27 May 2016, from time.com/4114009/paris-attacks-migrantcrisis-refugees-eu/.

Ryken, P.G., 2009, Luke Volume I: Chapters 1-12, Reformed expository commentary, P\&R Pub, Phillipsburg, NJ.

Schnabel, E.J., 2005, The First Gospel and Matthew's mission narrative, theological and historical perspectives, viewed 01 July 2020, from www.sbl-site.org > assets ) pdfs , Schnabel FirstPDF.

Schweizer, E., 1974, ' $\Psi$ UXn' in the New Testament', in G. Friedrich (ed.), Theological dictionary of the New Testament, vol. 9, pp. 637-656, William Eerdmans, Grand Rapids, Ml.

Schweizer, E., 1975, The good news according to Matthew, John Knox Press, Westminster.

Shezi, L., 2017, 6000 or 12 000? How many foreigners are locked in SA prisons? viewed 12 August 2017, from www.htxt.co.za/2017/07/10/how-many-foreignerssa-prisons/.

Skeldon, R., 2013, 'Global migration: Demographic aspects and its relevance for development technical paper', No. 2013/6, in United Nations Department of Economic and Social Affairs, viewed 27 March 2016, from https://www.un.org/ en/development/desa/population/migration/publications/technicalpapers/ en/development/desa/population/m
docs/EGM.Skeldon_17.12.2013.pdf.
Stanton, G.N., 1992, A Gospel for a new people: Studies in Matthew, T\&T Clark, Edinburgh.

Stein, T., 2018, 'Migrant or refugee - Does the label even matter?', Global Social Challenges, viewed 16 July 2020, from https://sites.manchester.ac.uk/globalsocial-challenges/2018/04/24/migrant-or-refugee-does-the-label-even-matter/.

Tesfai, Z., n.d., Migrant, refugee, asylum seeker; What's in a label?, viewed 16 July 2020, from https://shivafoundation.org.uk/migrant-refugee-asylumseeker-whats-in-a-label-by-zula-tesfai-youth-ambassador/.

Torrance, T.F., 2008, Incarnation: The person and life of Christ, InterVarsity Press (IVP) Academic, Downers Grove, IL.

Turner, D.L., 2008, Matthew: Baker exegetical commentary on the New Testament, Baker Academic, Grand Rapids, MI.

Ulrich, D.W., 2007, 'The missional audience of the gospel of Matthew', The Catholic Biblical Quarterly 69(1), 64-83.

Van Lennep, T., 2019, Migration I: Public opinion versus reality on immigration in South Africa, viewed 08 January 2020, from https://www.politicsweb.co.za/ opinion/migration-i-public-opinion-versus-reality-on-immig.

Viljoen, F.P., 2011, Matthews's portraits of Jesus: Six studies in Matthew, Potchefstroomse Teologiese Publikasies, Potchefstroom.

Viljoen, F.P., 2015, 'The double love commandment', In die Skriflig 49(1), a1869. https://doi.org/10.4102/ids.v49i1.1869

Walker, L.L., 2000, 'Heart', in D.N. Freedman, A.C. Myers \& A.B. Beck (eds.), Eerdmans dictionary of the Bible, p. 563, William Eerdmans, Grand Rapids, MI.

Wilkins, M.J., 2002, Zondervan illustrated Bible backgrounds commentary: Matthew, Zondervan, Grand Rapids, MI.

Williams, G., 2018, 'A place of hope: Matthew 22:34-40+', Theological Review 39, 119-124.

World Economic Forum, 2017, Migration and its impact on cities, viewed 28 April 2020 from http://www3.weforum.org/docs/Migration_Impact_Cities_report_2017_HR.pdf.

Wright, N.T., 1991, The climax of the covenant: Christ and the law in Pauline theology, T\&T Clark, Edinburgh.

Yeo, R., 2020, 'The regressive power of labels of vulnerability affecting disabled asylum seekers in the UK', Disability \& Society 35(4), 676-681. https://doi.org/10 $.1080 / 09687599.2019 .1639688$

Zetter, R., 1991, 'Labelling refugees: The forming and transforming of a bureaucratic identity', Journal of Refugee Studies 4(1), 39-62. https://doi.org/10.1093/jrs/4.1.39 